\title{
Collecting Anarchy: Continuing the Legacy of the Joseph A. Labadie Collection
}

The Joseph A. Labadie Collection at the University of Michigan is one of the oldest and most comprehensive collections of radical history in the United States, bringing together unique materials that document past as well as contemporary social protest movements. In addition to anarchism and labor movements, topics that were its original focus, the Collection today is particularly strong in civil liberties (with an emphasis on racial minorities), socialism, communism, colonialism and imperialism, American labor history through the 1930s, the Industrial Workers of the World (IWW or the Wobblies), the Spanish Civil War, sexual freedom, women's liberation, gay liberation, the underground press, and student protest movements. It contains more than 35,000 books and 8,000 periodicals (including nearly 800 currently received titles), but is also famous for its vast amounts of ephemeral materials: brochures, leaflets, clippings, and reprints, posters illustrating various aspects of protest, and numerous photographs, including ones of people prominent in the anarchist movement. Both the posters and photographs have been made available as online exhibits. ${ }^{1}$ In addition, last year the Digital Library Production Service and Special Collections Library at Michigan began a project to digitize the Anarchism Pamphlets from the collection. ${ }^{2}$

Named for a man who nearly 100 years ago began bringing together materials relating to anarchy and labor movements, the Labadie holdings have increased more than a thousandfold since they were first given to the University of Michigan. While recent curators have continued to be inspired by the original donation from Labadie, they have also expanded the breadth and depth of the collection, reflecting the changing times and social movements that have transpired over the past century. The Labadie Collection has taken on a life and meaning vastly larger than its beginning. Because the term "social protest" can be broadly interpreted, collecting policies for the Labadie materials have been blurred and stretched in

1. See www.lib.umich.edu/spec-coll/labadie/.

2. Available at http://quod.lib.umich.edu/1/labadie/. 
ways that can sometimes seem difficult to define, and the question frequently arises as to what to include in such a collection. Labadie's wide subject range makes it easy to accumulate materials; yet topics that were once considered controversial or radical—such as labor organizing or alternative sexuality—may not necessarily be so today. Many movements and ideas of the past have moved into the mainstream, raising the question as to whether or not we should continue collecting in those areas. To cease doing so would mean that we could make room for new materials that are the radical issues of today. On the other hand, to abruptly cease collecting in a subject area results in having only a part of the story, a move that would be a great disservice to our current and future researchers. Curators working with this collection are continuously facing decisions such as these, and having autonomy in their decision making, as well as the encouragement and backing of the library administration when needed, is extremely important in their jobs.

Understanding the historical origins of the Labadie Collection can serve to deepen one's appreciation for the truly unique way in which one man's vision became the library and archives that exist today. In addition to the collection he gave to the University of Michigan, records relating to Joseph Antoine Labadie have also been preserved, which serve to document his life. He was born in 1850 in the backwoods of Paw Paw, Michigan, where he was introduced to the life and language of the native Pottawatami tribes living nearby. Although he received almost no formal education, he was trilingual, speaking the native French and English of his family and learning Pottawatami from his neighbors. In his teens he was trained in the printing trade and went on the road as a tramp printer, working in print shops throughout Indiana, New York, Pennsylvania, Ohio, and Michigan and joining typographical unions everywhere he went. After marrying and settling in Detroit in the 1870s, Labadie became an organizer for the Knights of Labor. He acquired a printing press and used it to create little pamphlets containing his essays as well as poetry he wrote, along with contributions from his friends and other writers. Having almost no money, he printed on used scraps of paper and wallpaper, and bound the booklets with bits of leather. While he initially intended to sell these, he was not a successful entrepreneur, and chose instead to give most of them away. To make ends meet, he did printing jobs for businesses and organizations and wrote a regular syndicated newspaper column called "Cranky Notions," at the same time publishing several labor newspapers in Detroit in the late 1800s. He toured the lecture circuit and also corresponded with scores of people active in the turbulent labor, socialist, and anarchist movements of the period. Although his newspaper articles were tirades against the government and the status quo, many of his little booklets were love poems and affectionate greetings to his friends. It is said that he was much admired for his warmth, passion, and welcoming nature, by radicals and capitalists alike. 
By 1911, Labadie and his wife, Sophie, had collected and carefully preserved a vast amount of literature on social movements that included both his own writings and publications as well as works on the subject written by others. Even during this time, Labadie's collection was recognized as being both unique and valuable, and as a result a number of academic institutions in the surrounding area offered to house it for him. But Labadie insisted that it go to the University of Michigan, where it would be geographically close to his home. He also stated that this conservative institution needed some ideological balance in its collections. In a letter to John R. Commons of the University of Wisconsin, who had offered to house his collection, Labadie said, "After recovering from the shock produced on me by the suggestion of parting with [my collection], I made up my mind it should go where it was most needed—old moss-back Michigan—conservative, reactionary, and positively crass in some things ..."

The exact size of the original contribution is unknown, but the first shipment arrived in about 20 boxes. In addition to materials created on Labadie's printing press and his vast correspondence, there were also books, pamphlets, by-laws, newspapers, newsletters, announcements, membership cards, photographs, posters, and badges. Although the Board of Regents at the University of Michigan graciously accepted the gift, the then somewhat stuffy library administration was at a loss as to what to do with this radical trove of literature. For quite some time after the materials were deposited in the Library, absolutely nothing was done with them. The entire collection was placed in a corner, and when inquiring researchers asked to use it, they would be given a key and sent, on their own, into a locked cage area filled with boxes of unaccessioned, unprocessed, and uncataloged material. Undoubtedly, many items disappeared from the collection during that time.

This might have remained the fate of the materials had it not been for a wealthy Detroit activist, Agnes Inglis, whose involvement in radical political activities included organizing lectures for people such as anarchist and feminist Emma Goldman, rallying support for labor and civil liberties causes, and assisting and even putting up bail money for World War I draft law violators and political prisoners. In fact, her family eventually reduced her allowance to a modest living stipend so that she would not squander her inheritance on radical causes, as they feared she was likely to do. Inglis was acquainted with Jo and Sophie Labadie and knew of their donation to the University of Michigan Library, and she began using the Labadie Collection for her own research in the early 1920s. While her first encounter was probably much like everyone else's-i.e., working in a locked cage of materialsher inherent organizing instincts soon took over, and she remained at the Library to "sort out" the materials and attempt to bring some order to the chaos. This decision probably changed her life, for she stayed with the Labadie Collection for 
nearly 30 years. It is almost certain that without the work and dedication of Agnes Inglis, the Labadie Collection would probably not exist today. Labadie, himself, sent her many cards and letters expressing how thrilled he was that she was there, "taking care of things." In one letter he told her that the Labadie Collection would be " 0 " without her, while in another he stated that, "there ain't not to many Agnes Inglises floatin' around ... (m)uch to the world's ... loss.” Labadie even suggested that the Collection be renamed the Inglis-Labadie Collection, but Inglis declined, part of her virtue being that she did not want much recognition. In fact, she would most likely be happy just knowing that the Collection remains today-in large part due to her efforts - and delighted to find that it is so heavily used and well-funded, considering that, during the time she worked at the Library, there was not even money available for file cabinets in which to store the materials.

By the time Inglis began sorting out the Collection in the early 1920s, she was already in her early fifties. She was not a trained librarian, archivist, or historian, but she cared about the materials, and said in a letter to Labadie "it is true someone who cared had to begin ... [and] it is a big job to get started." Although she thought she would spend a few months "getting it started," this "Labor Library" work continued throughout Inglis's life. Being an anarchist and activist herself, she had a good sense of the subject matter, and knowledge of the people and events and movements that made up the collection. Her many connections and insatiable curiosity gave her access to a constant flow of information and materials. She initially worked as a volunteer, writing in 1927 that "I really don't want pay, for I am so much freer doing it the way I do. I could not be tied to either routine or hours ..." It was not until late 1929-more than five years after she commenced her workthat the library began to pay Inglis a salary. Fortunately, up until 1930, she also had the help of a Mr. Goodrich, who arranged for preserving much of the material in the Labadie Collection, as well as the support of the head Librarian, William Warner Bishop, who was himself dedicated to the preservation and access of the materials. It was Bishop who had special plates made for the books, pamphlets, and scrapbooks in the Labadie Collection.

When Jo Labadie died in 1933, the remainder of his collection was bequeathed to the Library through his three children. Agnes continued her work, bringing the archive to the forefront of "labor" libraries, as she called them, and during her tenure she increased its size dramatically. Her own correspondence with political and labor activists is extensive and now forms the Agnes Inglis Papers, which also contain notes and biographical information on many activists and writers of her era. It is a valuable resource in itself, as are all of the print and visual materials she collected and painstakingly preserved, bound, referenced, analyzed, and cataloged, in her own idiosyncratic way. She remained active throughout her life in politi- 
cal circles, writing letters, visiting political prisoners, and organizing lectures and fundraising events for the movement. Her extensive research into people and events, which she would then add to the growing collection, uncovered more sources: she scouted out materials, writing to living radicals, and to the families of deceased ones, as evidenced in her copious notes. In so doing, Inglis was able to preserve a history that would most likely otherwise have been lost forever. She asked her radical friends to donate items, and they did, happily - their diaries, journals, artwork, letters, autobiographies, photographs, posters, scrapbooks, as well as masses of books, journals, and newspapers, were all added to the Collection. She spent her days, and many nights as well, reading, writing, processing, and caring for the materials she knew were going to document the history of social protest. Her notes tell us that she always made time for visitors to the Labadie Collection, and even today some of the individuals who were fortunate enough to have made her acquaintance return to it.

Agnes died on January 29, 1952, at the age of 81 . Despite the promise by Dr. Warner Rice, the new Head Librarian, that the library would continue to add to the Labadie Collection, the position left vacant by Inglis was not filled. As a result, the Collection was once again neglected, and possibly ravaged by the unsupervised patrons who were given free access to the collection Inglis had worked so hard to organize. As a result, Inglis's precise filing and locating system were lost forever (though her thousands of index cards, mostly handwritten with notes and analytics, are still in use today, filed in an old card catalog cabinet).

It was not until 1960 that Edward Weber, who had been working as a reference librarian in the Social Sciences section of the Library, was assigned to the Labadie Collection. Weber brought his own anti-authoritarian attitude and social/political interests with him, in keeping with the spirit of the Collection and carrying on its tradition. During the 40 years he remained in that position, he significantly

\section{PERIODICALS SERVICE COMPANY \& SPRINGER}

We are pleased to announce our journal stock management agreement with Springer. For a list of Springer journals for which we now reprint all out-of-print volumes and back issues please visit: $\square$

\section{www.periodicals.com/springer.html}

11, Main Street, Germantown, NY 12526

Phone: 5185374700 Fax: 5185375899 E-mail: psc@periodicals.com 
expanded its holdings and extended the scope to include a wide range of rare materials. He was one of the first academic librarians to begin collecting materials related to "sexual freedom," and as a result, the University of Michigan's Library holds many early homophile and gay liberation publications not easily found elsewhere. He additionally used his vast knowledge of American and European history, applying a broader interpretation to the Collection to reflect changing times and movements. Because there was still no acquisitions budget, Weber relied on donations and sympathetic library workers, who "adjusted" the accounts and funneled subversive literature into the Collection. Weber himself was openly gay and an outspoken critic of censorship and ignorance, as well as a prolific letter writer. The extensive correspondence he generated throughout his tenure was later added to the Collection.

Even though the Labadie Collection became part of the Special Collections Library (then called the Rare Book Room) in 1964, it took until the mid-1970s before it was finally given its own book budget. For the first time in the history of the Collection, legitimate purchases could be made. Along with these new benefits, however, came administrative responsibilities, such as writing monthly reports and developing budget proposals, duties that Weber found unpleasant. Up until that time he had had free rein over most decisions pertaining to the Labadie Collection, but now it was a tradeoff, and he made the choice to adapt to his new place in the hierarchy. Armed with his new acquisitions budget, Weber began making documented purchases of underground newspapers, self-published pamphlets, and other materials. Most of these items cost very little at that time, since they were not yet seen as collectibles and were usually obtained directly from the publishers. To try to buy these same materials today, retrospectively through book dealers, can cost up to thirty times their original price, which is why it is financially prudent to make an educated guess to ascertain and to purchase newly published items, whenever possible, in what appears might become an important area to future researchers. Weber retired in 2000, having doubled or even tripled the size of the Collection and leaving a long legacy for a new generation. He died in April 2006.

In 1994 I was hired as the Assistant Curator and became the first trained archivist to be involved with the Labadie Collection. I began my work by learning about the many subjects and intricate filing systems that undergird the (by this time) immense Collection. My own connections with various activists and political movements have helped me to acquire new collections. Since its inception, the Labadie Collection has had a policy of collecting retrospective as well as contemporary materials that document radical movements and people throughout the world. Like Inglis and Weber before me, some of the ways I do 
this is by keeping up with current social issues in the radical press and contacting activists and writers to ask if they would consider donating their materials, always focusing on the fact that collecting materials not only about activism, but by activists is one of the hallmarks of the Labadie. I write to the elder activists and the young ones, to those who are local as well as to those far away; and if I learn about someone who might have a relevant collection, I contact them immediately. I attend radical gatherings, conferences, and book fairs as part of my collection development duties, which allows me to meet new activists and acquire new materials. Many people send things after I've had a chance to talk to them and, while I cannot be present at every event, friends and colleagues will often send things from events they've attended. In some cases, my position as an academic librarian grants me a certain degree of "carte blanche"; in other circles, I am considered immediately suspect. But for the most part, the donors share my deep concern about the world and the people in it, which usually provides an immediate rapport.

With a continually expanding Web presence, word of the Labadie Collection is spreading rapidly. On our Web site, one can view over 900 photographs, read descriptions of 100 archival collections, browse a list of over 9,000 vertical file subject headings, and explore a few of our exhibitions. The Labadie Collection today is recognized as one of the world's most complete collections of materials documenting the history of anarchism and other radical movements. It has a generous acquisitions budget, as well as access to trust funds, although we still get many donations out of people's trunks, attics, garages, basements, and even occasionally from someone's prison cell. It is used by a wide range of people, from noted scholars who travel to do research, to the many graduate and undergraduate students at the University and other nearby colleges who use its holdings of current and noncurrent periodicals to study past and present radical movements. It is part of my job and my passion to ensure that tradition contin-

\section{PERIODICALS SERVICE COMPANY}

are pleased to announce the agreement with

$$
\text { Palgrave Macmillan Ltd. }
$$

to manage backstock and supply originals or reprints of out-of-print journals older than the current and previous two years. For a list: $\square$

www.periodicals.com/palgravemac.html

To contact us:

11, Main Street, Germantown, NY 12526

Phone: 5185374700 Fax: 5185375899 E-mail: psc@periodicals.com 
ues. Jo Labadie passed on over 80 years ago, Agnes Inglis over 50 years ago, and now Ed Weber is gone as well, and the University administration still occasionally wonders what to make of it all. I know they sometimes bristle at the contents of the collection: but if they did not, I would wonder if I was adequately doing my job.

The planet has become a much smaller place since Agnes Inglis and Jo Labadie were here. Even so, I sometimes share their fear that, in this volatile world, someone might think such a collection should be destroyed. But that fear did not stop Inglis or Labadie from working to spread the word about it and solicit donations from "out of trunks and attics." Their original mission continues to inspire me. The Labadie Collection today is much more than the sum total of its creators, contributors, and curators. It continues to grow and develop in new directions, readily and freely serving many people. I think Jo Labadie would be proud to see that his vision of 100 years ago continues to grow and evolve to meet the changing needs of the time; and that, to me, is an invaluable service to offer.

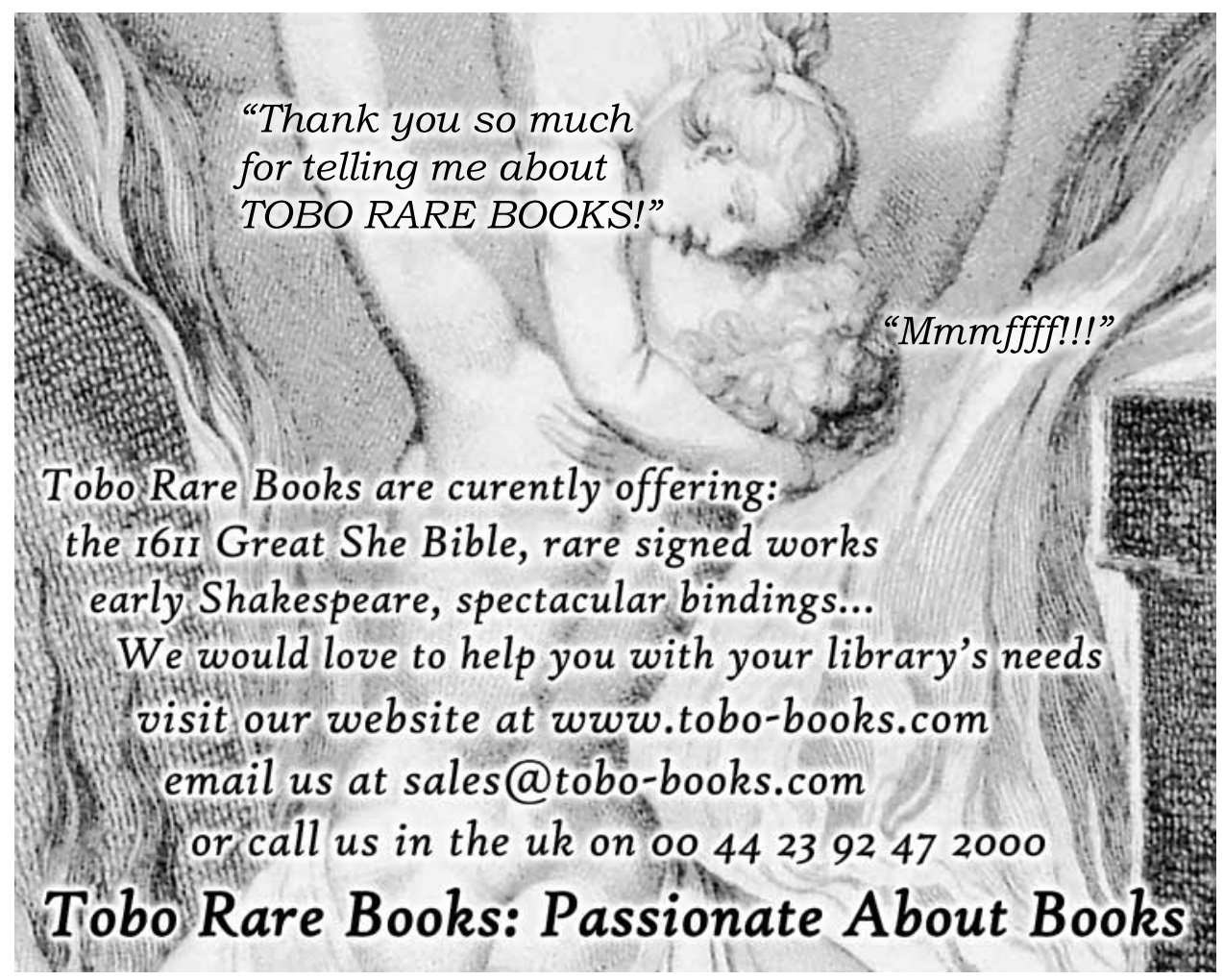

